\title{
Successful CEO Founder's Characteristics and Its Impact on Investment Return of Entrepreneurial Firms
}

\author{
Muhammad Haseeb \\ Faculty of Business and Accountancy, University of Malaya \\ Malaysia
}

\author{
Ali Awais Khalid \\ Lahore Business School, University of Lahore, Pakistan \\ aliawaischeema@gmail.com
}

\author{
Afaf Mudassar \\ UCP Business School, University of Central Punjab
}

Lahore, Pakistan

\begin{abstract}
Purpose/objectives - The purpose of this study is to test the impact of founder's personal characteristics on investment return of entrepreneurial firms operating in Silicon Valley from 2001 to 2015. Moreover, we extended the upper echelon theory by bridging the founder characteristics and investment returns of entrepreneurial firms in Silicon Valley as these firms have higher resources and it's interesting to observe findings in these firms.

Design/methodology/approach - The data of 765 entrepreneurial firms initially gathered from datastream and LexisNexis Academic database from 2001 to 2015 from which we retained 58 firms in our final sample after excluding financial firms, delisted, merged or acquired firms and firms having no data about CEOs characteristics.

Findings -Our findings suggest that age is positively and significantly related with the total return comparative and with the use of total investment return proxy the effect of age is negative and insignificant that suggests that older founders lose wealth. We find support to our second hypothesis regarding tenure that shows negative and highly significant impact on total return comparative and negative with the total investment return proxy but insignificant. Founder's over confidence is insignificantly related with the total comparative and investment returns.

Practical implications - The findings of this study will help the investment managers about the role successful CEOs plays in increasing the investment returns. By following our findings investors can invest in firms with successful CEOs to get higher returns.

Originality/value -This study is an attempt to extend the upper echelon theory by bridging the successful founder characteristics and investment returns of the entrepreneurial firm. For this study, the selection of successful CEOs of entrepreneurial firms and firm location in Silicon Valley provide a useful contribution to the upper echelon theory.

Keywords: Entrepreneurial firms, CEOs, Investment return, Upper Echelon Theory

\section{Introduction}

The creation of business is a crucial event in the life of founders that further forms the new markets and industries. This event requires a lot of effort that involves opportunity identification, decision making for capturing market value through exploitation of these opportunities, strategy formulation and implementation as well as overall organization of the new venture to create value (Erikson, 2001; More, 2018; Shane \& Venkataraman, 2000).

Hence, role of founder is most important that affects the survival or failure of entrepreneurial ventures and existing studies also focused on characteristics of entrepreneurs and how these factors affects new businesses (Abebe \& Tangpong, 2018; Kim, Lee, \& Kang, 2018; Liu, Fisher, \& Chen, 2018). Nonetheless, the effects of these factors on investment decisions and returns to investments are not discussed

empirically in the existing literature.In this study, we examine the following research question: "Do CEO entrepreneur's age, overconfidence and tenure affect the investment returns of entrepreneurial firms in Silicon Valley?" This research question contributes to literature by improving the understanding of entrepreneurial investment strategies and how founder characteristics affects the new business ventures. These founders not only create new businesses they also get the wealth from the business through value creation.

The existing literature identified different characteristics of founders such as prior experience for opportunity identification (Lundberg \& Rehnfors, 2018), knowledge before the start of new business (Cohen \& Levinthal, 1990; Teberga \& Oliva, 2018) and level of education (Reynolds, 1997). Although these existing studies investigated different characteristics of founders but they ignored the role of these factors in investment decisions of new business ventures. In
\end{abstract}

The current issue and full text archive of this journal is available at www.jraspublications.org/index.php/JRAS/issue/archive

Journal of Research in Administrative Sciences

V VI(II), 12-18, ISSN: 2664-2433 
the literature regarding finance investment decision is widely discussed such as under or over investment issues are discussed by examining the cash flows and level of investments (Cleary, 1999; Ek \& Wu, 2018; Fazzari, Hubbard, Petersen, Blinder, \& Poterba, 1988; Kaplan \& Zingales, 1997).

\section{Theory and Hypothesis Development}

The financial constraints are identified as the key factor in growth and survival of entrepreneurial firms as without the required finance rapid growth and diversification is not possible. Whited (1992) investigated how financially constrained firms act as getting debt for expansion increase the riskiness of firms and shareholders may lose in this scenario. The investment cash flows sensitivity and use of internal funds is discussed by Bhagat, Moyen, and Suh (2005) who finds that availability of internal funds depends of firm profitability.

\section{Capital Structure and Investment Theories}

These investment decisions by founders are not efficient most of the times because of imperfections in financial markets such as Modigliani and Miller (1958) identified that investors are affected by market inefficiencies and they are not always able to generate wealth for shareholders as investment and behavioral biases affects the decision making of CEO founders. The entrepreneurial companies may face agency costs and information asymmetries as managers have better information and sometimes they work on risky projects without informing the shareholders that cause over investment problems.

The other studies focused on investment sensitivities and cash flows for instance, Hoshi, Kashyap, and Scharfstein (1991) suggests that higher funds in cash flows is a positive signal and increase the chances of survival of these firms as in this case, these firms have more availability of internal funds those are used in positive NPV projects for value creation as internal funds are preferred over external financing according to the pecking order theory of capital structure (Frank \& Goyal, 2003; Myers, 1984). All of these studies only considered financial characteristics but ignored the manager/CEO or founder characteristics. The upper echelon theory provides the rational the founder characteristics affects the financial outcomes.

\section{Upper Echelon Theory}

The upper echelon perspective Hambrick and Mason (1984) suggests that characteristics of founders and CEOs, Managers affects the organizational choice and performance. The personal traits are more important in complex decision making such as strategic decisions i.e. exit strategies (merger and acquisitions), growth and investment strategies. Theory further suggests that age and experience of managers affect the firm performance as these factors positively or negatively affect the firms (Hambrick \& Mason, 1984).

Moreover, these founders and managers make decisions based on cognitive, physiological and social attributes of their personalities. Every manager interprets the things differently based on his prior knowledge and experience. The different studies considered these factors about managers and organizational outcomes, for instance, research and development expenses (Barker III \& Mueller, 2002; Bouslah, Linares-Zegarra, M'Zali, \& Scholtens, 2018), technological innovation Kitchell (1997), disclosure requirements Bamber, Jiang, and Wang (2010) and cash in hand in SME firms (Orens \& Reheul, 2013).

Yet, the significance of these studies is not extensive as the authors ignored financial outcomes associated with founder characteristics specially its role on investments strategies and returns associated with those investments for value creation. Therefore, we will try to fill this gap by linking upper echelon theories and investment strategies and outcomes so mainly we extend the investment theories and upper echelon perspective by linking them. Second, in this study we only considered successful founders according to earnest and young successful founder reports and we empirically examine personal attributes of those founders of firms located in Silicon Valley as we believe that those firms in that geographical area are best in technology, have better capital and further due to better education founders in that area are more vigilant and have the better knowledge than other firms in other areas. We contribute by investigating the research question "Do CEO founder's age, overconfidence and tenure affect the investment returns of entrepreneurial firms in Silicon Valley?"

This is the first study that examine the founder personal attributes and investment returns of entrepreneurial firms. We extended the upper echelon theory by Hambrick and Mason (1984) through linking the founder personal characteristics and investment returns and we also contribute by improving the methodology such as using panel regressions as well as OLS pooled regression as in most studies cross sectional and survey based data is used but we applied panel regressions with dummy variables and for robustness we used two proxies for investment return i.e. comparative and total investment return as dependent variables.

The remainder of this paper is carried out follows. Section 2 outlines the data collection and methodology. Section 3 shows results and discussion and finally, section 4 concludes the study.

\section{Research Methodology and Data Collection Data Collection}

The sample data for this study was gathered from LexisNexis Academic and Datastream database. Our initial sample of entrepreneurial firms in Silicon Valley includes 765 firms and then we excluded financial firms, delisted, merged, acquired or dead firms and those firms in which we don't have data of CEO founders. We left with 58 firms as the final sample. We gathered the data of financial constraints, investment returns, firm size, and other financial and investment indicators from the datastream database and for selection of successful founder's award using Earnest and Young entrepreneur of the year ${ }^{1}$ awards for identification of successful entrepreneurs in Northern California region where Silicon Valley is located in United States.

We gathered data from 2001 to 2015 as mostly technological and entrepreneurial business started in this time period. Moreover, selection of Silicon Valley entrepreneurs and their firms is important because these firms have more availability of finance and entrepreneurs are also well educated and it is interesting to investigate entrepreneurial firms located in this area.

\section{Research Methodology}

Panel data technique is applied for analysis of results as we have different cross-sectional units (firms) over different time. We improved the cross-sectional analysis technique that was used in different studies. Further, we also used dummy variables in the regressions. First, we used OLS regression and then we used the random effects approach as our founder characteristics are time invariant and correlate with the error term so we used the random effects model to solve this problem. For solving the biasness due to currencies, we only used variables in US dollars. We also excluded those firms with non-availability of founder characteristics data this will also reduce the biasness of results.

\section{Research Hypothesis}

We developed the following hypothesis for extending the upper echelon and capital structure theories and for testing the empirical models.

Upper echelon theory suggests that age is associated with risk aversion as older CEOs are risk averse while young founders love to take risk and they follow aggressive investment strategies so older CEO founders use internal findings and reluctant to take the risk by using debt. Further, recent studies, for instance, recent studies such as Bertrand and Mullainathan (2004) suggests that if older CEOs have controlling stakes than they follow aggressive strategies, on the 
other hand, young CEOs have more opportunities and they love to invest in new projects and ventures.

So we expect in hypothesis 1 that;

$\mathrm{H} 1$ : CEO entrepreneur age is related to entrepreneurial firm's investment returns.

The UET theory also suggests that CEOs and leader tenure plays a significant role in decision making as new CEOs use risk adverse strategies and they usually prefer internal financing and with an increase in tenure they take debt as well as a result of confidence in their abilities.

Thus, in hypothesis 2 we expect that;

$\mathrm{H} 2$ : There is a relationship among founder tenure and entrepreneurial firm's investment return.

\section{CEO overconfidence level (CEOOF)}

The overconfidence of managers and CEOs guide them to use debt financing (Abor, 2007). Further, (Graham, Harvey, \& Puri, 2013) finds that CEOs with the positive frame of mind use short-term debt as debt financing. Therefore, we expect in hypothesis 3;

H3: The CEO founder overconfidence affects the entrepreneurial firm's investment returns.

\section{Empirical Model:}

We have developed the following models for analysis of founder personal characteristics and investment returns.

In the first baseline model in equation (1), we have checked the founder characteristics impact on total return comparative and we explained the model as follows;

$$
\begin{gathered}
\text { TRETC }_{i, t}=\beta_{o}+\beta_{1} \text { AGE }_{i, t}+\beta_{2} \text { TENURE }_{i, t}+\beta_{3} \text { ENTOVC }_{i, t}+ \\
\beta_{4} \text { LEV V }_{i, t}+\beta_{5} L N T A S S E T_{i, t}+\beta_{6} \text { RESSAL L }_{i, t}+\beta_{7} \operatorname{EBEXPR}_{i, t}+ \\
\beta_{8} \operatorname{CLOSELY}_{i, t}+\mu
\end{gathered}
$$

Where;

The dependent variable is (TRETC) that is total annual return compared to the industry average and (LNTIR) is Natural log of Total investment return, (AGE) represent the age of CEO founder, (TENURE) indicates the number of years CEO founder stays in company, (ENTOVC) CEO founder overconfidence is the dummy variable coded as 1 if founder exercise options otherwise 0 . We also used control variables such as (LEV) Leverage is the ratio of total debt to total assets, (LNTASSET) is natural log of total assets, (RESSAL) shows research and development expenditures to sales ratio, (EBEXPR) is EBIT to interest expense ratio, (CLOSELY) shows the Number of closely held shares by investors and $\mu$ is error term.

In our second model, in equation (2) we have investigated, the firm size as the moderator and its influence on acquisition premium using an interaction term of firm size and CSR proxies as we expect the aggravated impact of CSR of small firms on acquisition premium in hypothesis 2 .

$$
\begin{gathered}
\operatorname{LNTIR}_{i, t}=\beta_{o}+\beta_{1} A G E_{i, t}+\beta_{2} \text { TENURE }_{i, t}+\beta_{3} E N T O V C_{i, t}+ \\
\beta_{4} L E V_{i, t}+\beta_{5} L N T A S S E T_{i, t}+\beta_{6} \operatorname{RESSAL}_{i, t}+\beta_{7} E B E X P R_{i, t}+ \\
\beta_{8} \operatorname{CLOSELY}_{i, t}+\mu
\end{gathered}
$$

Where;

The dependent variable (LNTIR) is natural log of total investment return, (AGE) represent the age of CEO founder, (TENURE) indicates the number of years CEO founder stays in company, (ENTOVC) CEO founder overconfidence is a dummy variable coded as 1 if founder exercise options otherwise 0 .We also used control variables such as (LEV) Leverage is the ratio of total debt to total assets, (LNTASSET) is natural log of total assets, (RESSAL) shows research and development expenditures to sales ratio, (EBEXPR) is EBIT to interest expense ratio, (CLOSELY) shows the Number of closely held shares by investors and $\mu$ is error term. 3. Results and Discussion:

The descriptive statistics of the variables are displayed in Table 1 in which we displayed mean, median and standard deviation to get the snapshot of the data. First on average $\$ 8640$ US is the total comparative return of these firms and its standard deviation is 2.00 and our second dependent variable is natural log of total investment return that is having the mean of $3.49 \%$ and median is $3.63 \%$ while standard deviation is also low that is $1.53 \%$. Further independent variables are included such as on average founder age is the 60.3 year of and standard deviation is 11.64 that shows the relatively older CEOs and founders in these entrepreneurial firms. Tenure is on average 20 years and its deviation from mean is 10.10 that also shows less deviation and founder overconfidence is also used as the independent variable and it is a dummy variable with mean 0.40 and standard deviation of 0.49 respectively. The other variables are used as controls and shows normal values except standard deviation of firm leverage that shows a high value of 250 . Further, firm size, leverage and research and development sale ratios display normal values of means, median and standard deviation.

\begin{tabular}{lcccc}
\hline \hline \multicolumn{4}{c}{ Table 1: Descriptive Statistics } & \\
\hline \hline \multicolumn{1}{c}{ Variables } & Mean & Median & Std. Dev. & N \\
\hline \hline Total Return Comparative & 8640.08 & 17.32 & 2.00 & 618 \\
LN Total Investment Return & 3.49 & 3.63 & 1.53 & 347 \\
Founder Age & 60.33 & 59.00 & 11.64 & 870 \\
Founder Tenure & 20.50 & 18.50 & 10.10 & 870 \\
Founder Overconfidence & 0.40 & 0.00 & 0.49 & 870 \\
Firm Leverage & 29.99 & 4.38 & 250.97 & 650 \\
Firm Size & 13.75 & 13.89 & 1.96 & 666 \\
R\&D Sales Ratio & 64.61 & 15.83 & 431.04 & 613 \\
EBIT Interest Expense Ratio & 302.83 & 4.05 & 2800.24 & 534 \\
Closely Held Shares & 15.13 & 12.50 & 42.59 & 601
\end{tabular}

Table 1 shows the descriptive analysis table where, (TRETC) is total annual return compared to the industry average, (LNTIR) is a Natural log of Total investment return, (AGE) represent the age of CEO founder, (TENURE) indicates a number of years CEO founder stays in company, (ENTOVC) CEO founder overconfidence is the dummy variable coded as 1 if founder exercise options otherwise 0.(LEV) Leverage is the ratio of total debt to total assets, (LNTASSET) is natural log of total assets, (RESSAL) shows research and development expenditures to sales ratio, (EBEXPR) is EBIT to interest expense ratio, (CLOSELY) shows the Number of closely held shares by investors.

Source: Own composition from Datastream and LexisNexis online Database

Table 2 displays the results of the correlation matrix for checking

\begin{tabular}{|c|c|c|c|c|c|c|c|c|c|c|}
\hline Variables & TRETC & LNTIR & AGE & TENURE & ENTOVC & LEV & LNTASSET & RESSAL & EBEXPR & CLOSELY \\
\hline TRETC & $\begin{array}{ll}1.0000 \\
\end{array}$ & & & & & & & & & \\
\hline LNTIR & -0.2427 & 1.0000 & & & & & & & & \\
\hline AGE & -0.0881 & -0.1950 & 1.0000 & & & & & & & \\
\hline TENURE & -0.0567 & -0.2255 & 0.6841 & 1.0000 & & & & & & \\
\hline ENTOVC & 0.0732 & 0.1697 & -0.0706 & -0.1972 & 1.0000 & & & & & \\
\hline LEV & 0.1598 & 0.1417 & 0.0145 & -0.0823 & 0.1003 & 1.0000 & & & & \\
\hline LNTASSET & 0.2877 & -0.2115 & -0.1286 & 0.1871 & -0.1965 & -0.1526 & 1.0000 & & & \\
\hline RESSAL & -0.0624 & -0.0005 & -0.0241 & -0.0280 & -0.0376 & -0.0396 & -0.0340 & 1.0000 & & \\
\hline EBEXPR & -0.0745 & 0.0182 & -0.0308 & 0.0780 & -0.0952 & -0.1086 & 0.0163 & -0.0750 & 1.0000 & \\
\hline
\end{tabular}
the correlation among independent variables as we see in the table 2 our all independent variables have the low correlation that is less than $80 \%$ that shows our data is free from multicollinearity problem and it is safe to run the regression analysis on these variable

Table 2: Correlation Matrix 
Successful CEO Founder's Characteristics and Its Impact on Investment Return of Entrepreneurial Firms

M. Haseeb, A. A. Khalid, A. Mudassar

CLOSELY

$-0.3884$

0.1939

$-0.0108$

0.1120

0.0974

$-0.0297$

$-0.0801$

$-0.0514$

0.1275

1.0000 
Table 2 shows the correlation table where, (TRETC) is total annual return compared to the industry average, (LNTIR) is Natural log of Total investment return, (AGE) represent the age of CEO founder, (TENURE) indicates the number of years CEO founder stays in company, (ENTOVC) CEO founder overconfidence is a dummy variable coded as 1 if founder exercise options otherwise 0. (LEV) Leverage is the ratio of total debt to total assets, (LNTASSET) is natural $\log$ of total assets, (RESSAL) shows research and development expenditures to sales ratio, (EBEXPR) is EBIT to interest expense ratio, (CLOSELY) shows the Number of closely held shares by investors.

Source: Own composition from Datastream and LexisNexis online Database

Table 3 shows the results of OLS regression and in Table 3 we see that Age is positively related with Total return comparative and significant at $1 \%$ while with the use of total investment return proxy the effect of age is negative and insignificant that suggests that higher age of founder increase the comparative return because older founders have better information and they can earn extra as compared to the industry average on the other hand, the negative effect of age on total investment return is due to the fact the older CEOs are risk averse and they lose as money a result (Bertrand \& Mullainathan, 2004). Therefore, we find support to our hypothesis 1. We find support to our second hypothesis is regarding tenure that is negatively and significantly related with a total return comparative and this is also negative with the use of total investment return but statistically insignificant. This negative influence suggests that CEOs with more tenure and experience are risk averse and they don't follow aggressive strategies as result of their investment return is lower (Abor, 2007; Graham et al., 2013). While founder over confidence is related with the total comparative and investment returns but it is statistically insignificant. Our control variables such as, firm size and closely held shares are highly significant.

Table 3: OLS Results of CEO Founder Characteristics On Total Comparative and Total Investment Return

\begin{tabular}{ccc}
\hline \hline Variables & $\begin{array}{c}\text { Total Comparative } \\
\text { Return }\end{array}$ & $\begin{array}{c}\text { Total Investment } \\
\text { Return }\end{array}$ \\
\hline \hline AGE & $8328^{* * * *}$ & -0.016 \\
TENURE & $(1683)$ & $(0.010)$ \\
& $-8433^{* * *}$ & -0.013 \\
ENTOVC & $(1,850)$ & $(0.011)$ \\
& -37258 & 0.120 \\
LEV & $(26907)$ & $(0.174)$ \\
& 2.833 & 0.004 \\
LNTASSET & $(39.38)$ & $(0.003)$ \\
& 10652 & $-0.134^{* *}$ \\
RESSAL & $(7475)$ & $(0.052)$ \\
& -1.319 & -5.260 \\
EBEXPR & $(33.93)$ & $(0.000)$ \\
CLOSELY & 1.339 & 5.410 \\
& $(4.369)$ & $(2.720)$ \\
Constant & $1,575^{*}$ & $0.0163^{* * *}$ \\
& $(855.4)$ & $(0.006)$ \\
Observations & $-479583^{* * *}$ & $6.351^{* * *}$ \\
$\boldsymbol{R}$-squared & $(150606)$ & $(1.073)$ \\
$\boldsymbol{F}$-test $\boldsymbol{p}$ & 368 & 216 \\
value & 0.072 & 0.152 \\
\hline \hline
\end{tabular}

Table 3 shows the OLS Pooled regression results (column 2 and 3). The dependent variables are (TRETC) that is total annual return compared to the industry average and (LNTIR) is a Natural log of Total investment return, (AGE) represent the age of CEO founder, (TENURE) indicates a number of years CEO founder stays in company, (ENTOVC) CEO founder overconfidence is a dummy variable coded as 1 if founder exercise options otherwise 0 . (LEV) Leverage is the ratio of total debt to total assets, (LNTASSET) is natural $\log$ of total assets, (RESSAL) shows research and development expenditures to sales ratio, (EBEXPR) is EBIT to interest expense ratio, (CLOSELY) shows the Number of closely held shares by investors. Standard errors are in parentheses and *, $* *, * * *$ indicate statistical significance at the 1,5 , and $10 \%$ levels, respectively.

Source: Own composition from Datastream and LexisNexis online Database

Table 4 shows the results of random effects regression and in Table 4 we see that Age is positively related with Total return comparative and significant at $1 \%$ while with the use of total investment return proxy the effect of age is negative and insignificant that suggests that higher age of founder increase the comparative return because older founders have better information and they can earn extra as compared to the industry average on the other hand, the negative effect of age on total investment return is due to the fact the older CEOs are risk averse and they lose as money a result (Bertrand \& Mullainathan, 2004). Therefore, we find support to our hypothesis 1.

We find support to our second hypothesis is regarding tenure that is negative and highly significantly related with the total return comparative and this is also negative with the use of total investment return but statistically insignificant. This negative influence suggests that CEOs with more tenure and experience are risk averse and they don't follow aggressive strategies as result of their investment return is lower. While founder over confidence is related with the total comparative and investment returns but it is statistically insignificant and its effect is negative in total comparative return and positive in total investment return (Abor, 2007). Finally, control variables such as, firm size and closely held shares are highly significant.

Table 4: Random effects Results of CEO Founder Characteristics On Total Comparative and Total Investment Return

\begin{tabular}{ccc}
\hline \hline Variables & $\begin{array}{c}\text { Total Comparative } \\
\text { Return }\end{array}$ & $\begin{array}{c}\text { Total Investment } \\
\text { Return }\end{array}$ \\
\hline \hline AGE & $39103 * * *$ & -0.0127 \\
& $(9001)$ & $(0.0213)$ \\
TENURE & $-36505 * * *$ & -0.0251 \\
& $(10411)$ & $(0.0226)$ \\
ENTOVC & -155291 & 0.0058 \\
& $(173497)$ & $(0.334)$ \\
LEV & -0.0029 & 0.0016 \\
& $(0.006)$ & $(0.0040)$ \\
LNTASSET & $25.16 * * *$ & $-0.125 *$ \\
& $(3.061)$ & $(0.0754)$ \\
RESSAL & -0.0005 & -0.00011 \\
& $(0.006)$ & $(0.00020)$ \\
EBEXPR & -0.0005 & 3.7687 \\
& $(0.0007)$ & $(2.7187)$ \\
CLOSELY & $-0.662 * * *$ & $0.0187 * *$ \\
& $(0.197)$ & $(0.0076)$ \\
Constant & $-1.4797 * * *$ & $6.4091 * * *$ \\
& $(462643)$ & $(1.652)$ \\
Observations & 368 & 216 \\
R-squared & 0.2614 & 0.0318 \\
\hline \hline
\end{tabular}

Table 4 shows the random effects results (column 2 and 3 ) results. The dependent variables are (TRETC) that is total annual return compared to the industry average and (LNTIR) is a Natural log of Total investment return, (AGE) represent the age of CEO founder, (TENURE) indicates a number of years CEO founder stays in company, (ENTOVC) CEO founder overconfidence is the dummy 
variable coded as 1 if founder exercise options otherwise 0 . (LEV) Leverage is the ratio of total debt to total assets, (LNTASSET) is natural $\log$ of total assets, (RESSAL) shows research and development expenditures to sales ratio, (EBEXPR) is EBIT to interest expense ratio, (CLOSELY) shows the Number of closely held shares by investors. Standard errors are in parentheses and *, $* *, * * *$ indicate statistical significance at the 1,5 , and $10 \%$ levels, respectively.

Source: Own composition from Datastream and LexisNexis online Database

\section{Conclusion}

We examined the impact of CEO founder characteristics and investment return from 2001 to 2015 of entrepreneurial firms located in Silicon Valley. We classified founder characteristics such as age, overconfidence and tenure and checked its impact on total comparative and total investment return.

Overall, our findings are as follows that shows that age is positively related with the total return comparative and significant at $1 \%$ while with the use of total investment return proxy the effect of age is negative and insignificant that suggests that older founders lose the wealth. We find support to our second hypothesis is regarding tenure that is negatively and highly significantly related with the total return comparative and this is also negative with the use of total investment return but statistically insignificant.

While founder over confidence is related with the total comparative and investment returns but it is statistically insignificant and its effect is negative in total comparative return and positive in total investment return. Hence, we contribute to the literature by extending the upper echelon theory by bridging it with investment strategies of founders, methodological contributions include the analysis through random effects estimation. Therefore, findings of this study guides the policy makers about how to invest and what is the relationship of investment strategies with founder's personalities.

\begin{tabular}{|c|c|}
\hline \multicolumn{2}{|c|}{ Table 5: Variables Definitions } \\
\hline Variables & Definitions \\
\hline $\begin{array}{l}\text { Total Return } \\
\text { Comparative }\end{array}$ & $\begin{array}{l}\text { Total annual return compared to the } \\
\text { industry average }\end{array}$ \\
\hline $\begin{array}{l}\text { LN Total Investment } \\
\text { Return }\end{array}$ & Natural log of Total investment return \\
\hline Founder Age & Age of CEO founder \\
\hline Founder Tenure & $\begin{array}{l}\text { Number of years CEO founder stays } \\
\text { in company. }\end{array}$ \\
\hline $\begin{array}{l}\text { Founder } \\
\text { Overconfic }\end{array}$ & $\begin{array}{l}\text { Dummy variable coded as } 1 \text { if founder } \\
\text { exercise options otherwise } 0 .\end{array}$ \\
\hline Firm Leverage & $\begin{array}{l}\text { It is the ratio of total debt to total } \\
\text { assets }\end{array}$ \\
\hline Firm Size & Natural log of total assets \\
\hline R\&D Sales Ratio & $\begin{array}{l}\text { Research and development } \\
\text { expenditures to sales ratio }\end{array}$ \\
\hline $\begin{array}{l}\text { EBIT Interest Expense } \\
\text { Ratio }\end{array}$ & EBIT to interest expense ratio \\
\hline Closely Held Shares & $\begin{array}{l}\text { Number of closely held shares by } \\
\text { investors. }\end{array}$ \\
\hline
\end{tabular}

\section{References:}

i. Abebe, M. A., \& Tangpong, C. (2018). Founder-CEOs and corporate turnaround among declining firms. Corporate Governance: An International Review, 26(1), 45-57.

ii. Abor, J. (2007). Corporate governance and financing decisions of Ghanaian listed firms. Corporate Governance: The international journal of business in society, 7(1), 83-92.

iii. Bamber, L. S., Jiang, J., \& Wang, I. Y. (2010). What's my style? The influence of top managers on voluntary corporate financial disclosure. The accounting review, 85(4), 1131-1162.

iv. Barker III, V. L., \& Mueller, G. C. (2002). CEO characteristics and firm $\mathrm{R} \& \mathrm{D}$ spending. Management Science, 48(6), 782-801.

v. Bertrand, M., \& Mullainathan, S. (2004). Are Emily and Greg more employable than Lakisha and Jamal? A field experiment on labor market discrimination. The American economic review, 94(4), 991-1013.

vi. Bhagat, S., Moyen, N., \& Suh, I. (2005). Investment and internal funds of distressed firms. Journal of Corporate Finance, 11(3), 449-472.

vii. Bouslah, K., Linares-Zegarra, J., M'Zali, B., \& Scholtens, B. (2018). CEO risk-taking incentives and socially irresponsible activities. The British Accounting Review, 50(1), 76-92.

viii. Cleary, S. (1999). The relationship between firm investment and financial status. The Journal of Finance, 54(2), 673-692.

ix. Cohen, W. M., \& Levinthal, D. A. (1990). Absorptive capacity: A new perspective on learning and innovation. Administrative science quarterly, 128-152.

x. Ek, C., \& Wu, G. L. (2018). Investment-cash flow sensitivities and capital misallocation. Journal of Development Economics, 133, 220-230.

xi. Erikson, T. (2001). "The promise of entrepreneurship as a field of research": a few comments and some suggested extensions. Academy of management Review, 26(1), 1213.

xii. Fazzari, S. M., Hubbard, R. G., Petersen, B. C., Blinder, A. S., \& Poterba, J. M. (1988). Financing constraints and corporate investment. Brookings papers on economic activity, 1988(1), 141-206.

xiii. Frank, M. Z., \& Goyal, V. K. (2003). Testing the pecking order theory of capital structure. Journal of financial economics, 67(2), 217-248.

xiv. Graham, J. R., Harvey, C. R., \& Puri, M. (2013). Managerial attitudes and corporate actions. Journal of financial economics, 109(1), 103-121.

xv. Hambrick, D. C., \& Mason, P. A. (1984). Upper echelons: The organization as a reflection of its top managers. Academy of management Review, 9(2), 193206.

xvi. Hoshi, T., Kashyap, A., \& Scharfstein, D. (1991). Corporate structure, liquidity, and investment: Evidence from Japanese industrial groups. The Quarterly Journal of Economics, 33-60.

xvii. Kaplan, S. N., \& Zingales, L. (1997). Do InvestmentCash Flow Sensitivities Provide Useful Measures of Financing Constraints? The Quarterly Journal of Economics, 112(1), doi:10.1162/003355397555163

xviii. Kim, B., Lee, S., \& Kang, K. H. (2018). The moderating role of CEO narcissism on the relationship between uncertainty avoidance and CSR. Tourism Management, 67, 203-213.

xix. Kitchell, S. (1997). CEO characteristics and technological innovativeness: A Canadian perspective. Canadian Journal of Administrative Sciences/Revue Canadienne des Sciences de l'Administration, 14(2), 111-121.

xx. Liu, D., Fisher, G., \& Chen, G. (2018). CEO Attributes and Firm Performance: A Sequential Mediation Process Model. Academy of Management Annals, 12(2), 789816.

xxi. Lundberg, H., \& Rehnfors, A. (2018). Transnational entrepreneurship: opportunity identification and venture creation. Journal of International Entrepreneurship, 126. 
xxii. Modigliani, F., \& Miller, M. H. (1958). The cost of capital, corporation finance and the theory of investment. The American economic review, 48(3), 261-297.

xxiii. More, D. (2018). Creating Business Magic: How the Power of Magic Can Inspire, Innovate, and Revolutionize Your Business: Mango Media Inc.

xxiv. Myers, S. C. (1984). The capital structure puzzle. The Journal of Finance, 39(3), 574-592.

xxv. Orens, R., \& Reheul, A.-M. (2013). Do CEO demographics explain cash holdings in SMEs? European Management Journal, 31(6), 549-563.

xxvi. Reynolds, P. D. (1997). Who starts new firms? Preliminary explorations of firms-in-gestation. Small Business Economics, 9(5), 449-462.

xxvii. Shane, S., \& Venkataraman, S. (2000). The promise of entrepreneurship as a field of research. Academy of management Review, 25(1), 217-226.

xxviii. Teberga, P. M. F., \& Oliva, F. L. (2018). Identification, Analysis and Treatment of Risks in the Introduction of New Technologies by Start-ups. Benchmarking: An International Journal(just-accepted), 00-00.

xxix. Whited, T. M. (1992). Debt, liquidity constraints, and corporate investment: Evidence from panel data. The Journal of Finance, 47(4), 1425-1460. 